\title{
5.2. НЕКОТОРЫЕ ПОДХОДЫ К ОПРЕДЕЛЕНИЮ УРОВНЯ СРЕДНЕЙ ЗАРАБОТНОЙ ПЛАТЫ В СФЕРЕ ЗДРАВООХРАНЕНИЯ ИРКУТСКОЙ ОБЛАСТИ
}

\author{
Ерженин Р.В., к.э.н., доцент кафедры стратегического и финнансового менеджмента
}

\section{Байкальская международная бизнес-школа, Иркутский государственный университет, г. Иркутск}

В данном исследовании рассматриваются некоторые вопросы исполнения региональными органами власти социальных указов Президента РФ, принятых в мае 2012 г. Мониторинг исполнения осуществления указов Президента РФ, производимый различными региональными государственными структурами, представляет населению региона однобокую картину достижения целевых показателей, заданных указами. К одному из действенных методов в получении достоверной информации относится общественный мониторинг, о важности которого не раз отмечалось на государственном уровне. Для проведения оценки исполнения указа Президента РФ, согласно которому заработная плата определенной категории персонала должна быть не менее средней по региону, автором как общественником использовались открытые для оценки данные о результатах деятельности учреждений, размещенные на официальном сайте Федеральной службы государственной статистики. На этапе предварительного анализа автором были извлечены данные из фотокопий отчетов учреждений о средней заработной плате сотрудников учреждений за 2018 г. и представлены в структурированном виде в сети Интернет для общественного изучения. Объектами наблюдения в данной работе стали учреждения здравоохранения Иркутской области. Предметом оценки выбран уровень средней заработной платы врачей и медицинского персонала. В основу подхода к расчету показателей для оценки достижения уровня заработных плат отдельных категорий работников бюджетной сферы, определенных соответствующим указом, был положен принцип, используемый при анализе дифференциации доходов населения. Рассчитанные по этому принципу показатели средней заработной платы, средней модальной и средней медианной заработной платы не только подтвердили факт недостижения целевых показателей, отраженный также и в данных официального сайта для размещения информации о государственных (муниципальных) учреждениях, но и указали на значительный разрыв между минимальными средними зарплатами и максимальными. На основе полученных данных автором исследования были сделаны выводы о недостоверности публикуемых органами исполнительной власти Иркутской области сведений, согласно которым средние заработные платы отдельных категорий работников ссеры здравоохранения достигли установленных указом целевых показателей в полном объеме. В результате проведенной общественной оценки уровня средней заработной платы было установлено обратное - только у половины врачей и медсестер учреждений здравоохранения Иркутской области средняя заработная плата в 2018 г. достигла установленных соответствующим указом показателей. Предложенный в статье подход к оценке уровня заработных плат в сфере здравоохранения может также использоваться для проведения общественной оценки уровня средних заработных плат в сфере образования и культуры.

\section{Литература}

1. Ответы на вопросы Правительства Саратовской области по мониторингу реализации указов Президента РФ от 7 мая 2012 г. №597 «О мероприятиях по реализации государственной социальной политики», от 1 июня 2012 г. №761 «О национальной стратегии действий в интересах детей на 2012-2017 гг.» и от 28 декабря 2012 г. №1688 «О некоторых мерах по реализации государственной политики в сфере защиты детей-сирот и детей, оставшихся без попечения родителей, а также программы поэтапного совершенствования системы оплаты труда в государственных (муниципальных) учреждениях, на 2012-2018 гг,, утвержденной распоряжением Правительства РФ от 26 ноября 2012 г. №2190-р [Электронный ресурс] : инфрормация М-ва труда РФ от 28 нояб. 2013 г. Доступ из справ.-правовой системы «Консультант Плюс».

2. Василенко С.И. Мониторинг исполнения майских указов Президента РФ Общероссийским народным фронтом [Текст] / С.И. Василенко // Развитие современного региона: вопросы науки и практики : сб. науч. ст. по мат-лам IX Междунар. студ. науч.-практ. конф. - 2016. - С. 60-63.

3. Гражданская защита [Текст] : энциклопедия : в 4 т. Т. 2 : К - О. - М. : ФГБУ ВНИИ ГОЧС (ФЦ), 2015.

4. Карасев О.И. и др. Методологические проблемы расчета использования показателя средней заработной платы на региональном уровне [Текст] / О.И. Карасев, Л.А. Карасева, А.А. Охрименко // Вопросы статистики. - 2016. - №12. - С. 3-12.

5. Конаков В.В. и др. Мониторинг реализации в республике Мордовия указов Президента Российской Федерации от 7 мая 2012 [Текст] : аналит. доклад / В.В. Конаков, Р.Р. Агишев, В.П. Миничкина, О.Н. Баринова, Т.И. Кирдяшкина, И.В. Манаева, Е.С. Рункова, В.А. Сихиков. - Саранск, 2014

6. Майкова Э.Ю. и др. Власть и социум: проблемы фрормирования гражданского общества в России [Текст] / Э.Ю. Майкова, М.В. Блохина, Л.Г. Григорьев, Е.В. Симонова. - Тверь, 2009.

7. Позднякова Т.М. Средняя заработная плата: подходы к определению показателя [Текст] / Т.М. Позднякова // Статистика и экономика. - 2017. - Т. 14 ; №4. - С. $82-89$.

8. Президент России. События. Заседание Комиссии по мониторингу достижения целевых показателей социальноэкономического развития [Электронный ресурc]. - URL : http://kremlin.ru/events/president/news/51917.

9. РБК: Зарплаты бюджетников достигли целей из майских указов лишь в 16 регионах. Что помешало властям субъектов выполнить поручения Путина [Электронный ресурc]. - URL : https://www.rbc.ru/economics/17/04/2019/ 5cb5e37b9a794739af1a2c75.

10. Тополева-Солдунова Е.А., Коротеева О.В. Общественный мониторинг социальных указов Президента [Текст]/ Е.А. Тополева-Солдунова, О.В. Коротеева // Государственная служба. - 2013. - №3. - С. 6-9.

11. Усачева И.Ю. Анализ дифференциации доходов населения Рязанской области [Текст] / И.Ю. Усачева // Вестн. Рязанского гос. ун-та им. С.А. Есенина. - 2015. - №2. -С. 133-146.

12. Федеральная служба государственной статистики [Электронный ресурc]. - URL : https://irkutskstat.gks.ru/ folder/36503.

\section{Ключевые слова}

Указы Президента; общественный мониторинг; модальная средняя; медианная средняя; зарплата; врачи; медперсонал.

Ерженин Роман Валерьевич 


\section{РЕЦЕНЗИЯ}

Актуальность темы обусловливается тем, что современный уровень развития интернет-технологий предоставляет доступ к большим объемам публичной информации по самым различным аспектам жизни и деятельности граждан и, как следствие, - широчайшие возможности по анализу такого рода информационных материалов

Тематика статьи представляет несомненный интерес, поскольку вопросы анализа исполнения первых «майских указов» Президента РФ в настоящее время приобрели особую важность. Кроме того, в рецензируемой статье вполне ясно изложена и гражданская позиция автора, которая сформировалась у него на основе доминирующей в государстве новой политики открытости.

Научная новизна и практическая значимость. Статья относится к сфере исследований проблем извлечения знаний и значимой информации из крупных и сложных массивов данных, представленных на официальных интернет-ресурсах. Обработка доступной информации о средней заработной плате с использованием инструментария математической статистики позволила выявить скрытые от взгляда простого наблюдателя закономерности, происходящие в сфере здравоохранения Иркутской области. Значимость проведенного исследования состоит в том, что автор структурировал машиночитаемую информацию и проанализировал ее, выполнив тем самым независимую оценку исполнения Указов Президента РФ. По результатам анализа было выявлено расхождение между предоставленными данными и реальными значениями соответствующих показателей.

Особенно хотелось бы отметить вывод о том, что «игнорирование функции контроля, в конечном итоге, привело к искажению общего представления о действительности на местах и не позволяет адекватно оценивать объем финансовых ресурсов, необходимый для исполнения намеченных Президентом РФ целей в повышении уровня зарплат».

Заключение: текст статьи хорошо структурирован, включает методологические и практические аспекты, поэтому рецензируемая статья полностью отвечает требованиям, предъявляемых к научным публикациям, и может быть рекомендована к опубликованию в открытой печати.

Гутаари Р.Д., д.э.н., профессор, профессор кафедры автоматизированных систем ФГБОУ ВО «Иркутский национальный исследовательский технический университет», г. Иркутск

DOI 10.38097/AFA.2020.73.82.011 